\section{Occurrence of Salmonella infection and antimicrobial susceptibility for local Salmonella isolates from different sources in a cross-sectional study}

Shaymaa Abdelmalek, ${ }^{1}$ Mona Kadry, ${ }^{2}$

Esraa A. Elshafiee, ${ }^{2}$ Wafy Hamed, ${ }^{3}$

Ihab Mohamed Moussa, ${ }^{4,5}$

Khalid S. Al-Maary, ${ }^{4}$

Ayman S. Mubarak, ${ }^{4}$

Hassan A. Hemeg, ${ }^{6}$ Ayman Elbehiry ${ }^{7,8}$

${ }^{1}$ Department of Microbiology and Immunology, Faculty of Veterinary Medicine, Cairo University, Giza, Egypt; ${ }^{2}$ Department of Zoonosis, Faculty of Veterinary Medicine, Cairo University, Giza, Egypt; ${ }^{3}$ Medical Laboratory Specialist, Quesna, Menofiea, Egypt; ${ }^{4}$ Department of Botany and Microbiology, College of Science, King Saud University, Riyadh, Saudi Arabia; ${ }^{5}$ Department of Microbiology, Faculty of Veterinary Medicine, Cairo University, Giza, Egypt; ' Department of Medical Technology/Microbiology, College of Applied Medical Science, Taibah University, Madinah, Saudi Arabia; ${ }^{7}$ Department of Bacteriology, Mycology and Immunology, Faculty of Veterinary Medicine, University of Sadat City, Egypt; ${ }^{8}$ Department of Public Health, College of Public Health and Health Informatics, Qassim University, Buraydah, Saudi Arabia

\footnotetext{
Abstract

Salmonellosis is a considerable public health problem worldwide, with high economic importance in developed countries. The main purpose of this study was to determine the prevalence of Salmonella infection and antibiogram analysis of isolated strains in a cross-sectional study in Egypt 20162017. The study investigated twenty-eight Salmonella isolates from different areas in Egypt and different types of samples, such as human stool (9.3\%), Egyptian cattle egrets and storks $(28.5 \%)$ and grilled chicken from electric grills (36.6\%). No isolates were detected from grilled chicken from charcoal grills or drinking water. The main Salmonella serotype detected in the isolates was S. typhimurium (86.5\%). Molecular characterization of the invA gene by PCR was carried out and then confirmed by sequencing, and the results were submitted
}

to GenBank. Antibiogram analysis of Egyptian isolates carried out on 9 antimicrobial discs reported that the routine regimes of treatment were not yet effective for recent new Salmonella generations in 2016-2017. The new isolates could be treated with levofloxacin, cefaperazone/sulbactam, chloramphenicol, imipenem or meropenem.

\section{Introduction}

Salmonella is a gram-negative, facultative anaerobic bacteria belonging to the family Enterobacteriaceae (Barlow and Hall, 2002). It has been associated with a wide spectrum of infectious diseases, including typhoid salmonellosis and nontyphoid salmonellosis (NTS). Salmonellosis is a considerable public health problem worldwide, contributing to the economic loss of both industrialized and underdeveloped countries due to the costs associated with control and treatment of the disease (Crump et al., 2004). The most common manifestation of Salmonella infection is gastroenteritis followed by bacteraemia and fever. Salmonella has the ability to adapt within a variety of animal hosts, including humans (Allerberger et al., 2003; Majowicz et al., 2010). Salmonella is the most important foodborne pathogen and is mostly found in poultry, egg and dairy products; furthermore, fresh fruits and vegetables are a very important source of food involved in Salmonella transmission (Pui et al., 2011; Silva et al., 2011). Uncooked animal products from poultry, cattle and pigs are another important source of infection. Antibiotic resistance is a substantial problem related to Salmonella and increases the public health importance of Salmonella because of the high virulence and increasing morbidity rates of infected patients (Chiu et al., 2002).

In Egypt, the spread of Salmonella infection depends on socioeconomic factors, including educational level, sanitation, poor habits and misuse of antibiotics, which all help in the spread and persistence of Salmonella infection in urban, suburban and rural areas. Our work aimed to study the occurrence of Salmonella strains isolated and identified from different sources in different areas in Egypt. Quesna and Menoufia were used as rural area models, and Cairo and Giza were used as urban area models from 2016-2017. Molecular identification of isolated Salmonella strains was performed using PCR and sequencing of the inv A gene. Antibiogram analysis of recent Salmonella isolates is very important for the evaluation of currently used antibiotics in
Correspondence: Ayman Elbehiry, Department of Public Health, College of Public Health and Health Informatics, Qassim University, Buraydah, Saudi Arabia Tel.: +966532207969.

E-mail: aymanella2007@yahoo.com

Key words: Salmonella, occurrence, cross sectional, molecular, antibiogram, MDR.

Acknowledgments: The authors extend their appreciation to the Deanship of Scientific Research at King Saud University for supporting the work through the research group project No.: RG-162.

Contributions: the authors contributed equally.

Conflict of interest: the authors declare no potential conflict of interest.

Funding: none

Received for publication: 31 August 2019

Revision received: 25 October 2019.

Accepted for publication: 4 November 2019.

This work is licensed under a Creative Commons Attribution-NonCommercial 4.0 International License (CC BY-NC 4.0).

(C) Copyright: the Author(s), 2019

Licensee PAGEPress, Italy

Italian Journal of Food Safety 2019; 8:8525

doi:10.4081/ijfs.2019.8525

the treatment of salmonellosis. After checking the treatment strategies in the study locations, we found that approximately $90 \%$ of physicians treat adults $>18$ years with ciprofloxacin (CIP), patients $<18$ years are treated with cefotaxime (CTX) for 3 days, and the course is completed with azithromycin (AZM). Evaluation of these treatment strategies and selection of a highly effective antibiotic for isolated Salmonella strains are very important targets. Studying the occurrence of Salmonella infection in the aforementioned areas in Egypt can help emphasize the main points involved in disease control.

\section{Materials and Methods}

\section{Samples}

Human samples: Seventy-five stool samples were collected from clinically affected persons showing different clinical signs, such as fever, enteritis and diarrhoea. Serological examination of all blood samples was performed using the Widal test (Salmonella Ag O and H). Of the 75 samples, 25 were human stool samples from 
Quesna and Menoufia, and 50 were human stool samples from Giza and Cairo.

Carriers: Thirty-five samples were collected from storks and cattle egret mainly in rural areas. The liver and gallbladder were obtained for cultivation.

Foodstuffs: This study used 50 grilled chickens from different restaurants in Cairo, Giza and Menoufia, 20 grilled chickens from charcoal grills and 30 grilled chickens from multilayer electric grills.

Drinking water: Fifteen drinking water samples were collected with a volume of 5 litres each. The 5 litres were filtered, and the filter that contained the filtered bacterial load was cultivated.

\section{Isolation of Salmonella spp.}

Non-selective pre-enrichment: Twentyfive grams of human stool or grilled chicken were weighed and added to $225 \mathrm{~mL}$ of buffered peptone water (Sigma Aldrich, USA). The liver and gallbladder of carriers and the filter that contained bacterial load in the water were also inoculated and incubated at $37^{\circ} \mathrm{C}$ overnight (ISO, 1993; Post, 1997).

Selective pre-enrichment: A total of 100 $\mu \mathrm{L}$ of cultured buffered peptone water was transferred into $10 \mathrm{~mL}$ of Rappaport Vassiliadis soy peptone broth (RVS) and incubated at $41.5^{\circ} \mathrm{C}$ for $24 \mathrm{hrs}$ in a shaker incubator.

Streaking on selective media: A loopful of RVS broth was streaked on XLD and Hektoen enteric (HE) agar and incubated at $37^{\circ} \mathrm{C}$ for $24 \mathrm{hrs}$

\section{Biochemical identification of isolat- ed Salmonella}

Single colonies of the isolates on selective media were selected and subcultured on nutrient agar medium and then incubated at $37^{\circ} \mathrm{C}$ for $24 \mathrm{hrs}$. Single colonies from nutrient agar were selected and cultivated into triple sugar iron (TSI) slants, citrate slants and urea hydrolysis test slants, which were incubated at $37^{\circ} \mathrm{C}$ for $24 \mathrm{hrs}$ (ISO, 1993).

\section{Serological identification of Salmonella isolates}

The Salmonella isolates were preliminarily identified biochemically by serological identification according to Kauffman (1961) in the Microbiological Laboratory of the Ministry of Health.

\section{Molecular diagnosis by PCR}

All Salmonella isolates were tested by invA gene PCR (Rahn et al., 1992).

DNA extraction: The local Salmonella isolates were grown on nutrient agar medium, and the bacterial cells were harvested from the culture plates by a sterile cotton swab and placed into Eppendorf tubes containing $1 \mathrm{X}$ phosphate buffered saline (PBS) and mixed well. Then, centrifugation was performed at $9000 \times \mathrm{g}$ for $5 \mathrm{~min}$ (washing was repeated in PBS three times), and the sample was washed once with sterile deionized distilled water. Centrifugation was then performed at $9000 \times \mathrm{g}$ for $5 \mathrm{~min}$, and the supernatant was removed. Then, the bacterial pellet was suspended in $100 \mu \mathrm{L}$ of sterile deionized distilled water. The suspension was heated in a heat block (Grant-Bio, England) at $100^{\circ} \mathrm{C}$ for $5 \mathrm{~min}$ and then immediately cooled in ice water. Then, the samples were centrifuged, and the supernatant (DNA) was removed (Wang et al., 1996).

Primers: As indicated in Table 1, invA forward and reverse primers designed by Rahn et al. (1992) were used.

PCR amplification and electrophoresis: PCR amplification was carried out in a 25 $\mu \mathrm{L}$ reaction mixture containing $12.5 \mu \mathrm{L}$ of 2X Green Master Mix (EmeraldAmpGT PCR 2X Master Mix, A2201-1, Takara), 0.5 $\mu \mathrm{L}(25 \mathrm{pmol})$ of each primer (invA F and R), $2 \mu \mathrm{L}$ of extracted DNA and $9.5 \mu \mathrm{L}$ of nuclease free water (Thermo Scientific, \#R0581). The PCR cycling parameters consisted of denaturation at $94^{\circ} \mathrm{C}$ for $5 \mathrm{~min}$ followed by 30 cycles of $94^{\circ} \mathrm{C}$ for $30 \mathrm{~s}, 64^{\circ} \mathrm{C}$ for $40 \mathrm{~s}$ and $72^{\circ} \mathrm{C}$ for $30 \mathrm{~s}$. A final extension step was then carried out at $72^{\circ} \mathrm{C}$ for $7 \mathrm{~min}$ (Rahn et al., 1992). All reaction products were analysed by electrophoresis using $1.5 \%(\mathrm{w} / \mathrm{v})$ agarose gels in $1 \mathrm{X}$ TAE running buffer at $100 \mathrm{~V}$ for $30 \mathrm{~min}$ and imaged using a Spectroline UV transilluminator (Slimline Series, USA).

Invasive protein A (invA) gene products sequencing and bioinformatics analysis

PCR products generated from the invA gene in selected isolates of Salmonella were sent to be sequenced at the Animal Health Research Institute (AHRI) in Dokki, ElGiza. The PCR products were purified using the GeneJET PCR Purification Kit (Thermo) and sequenced on a DNA sequencer. The sequencing step was conducted with the Big Dye Terminator V3.1 Cycle Sequencing Kit (Applied Biosystems). The obtained sequences were determined by BLAST analysis with sequences available in GenBank (NCBI). Phylogenetic tree analysis was used to assess the relatedness of the gene sequences recovered from different sources. BioEdit software was used for Clustal W multiple sequence alignment and sequence identity matrix, and MEGA7 software was used for the construction of phylogenetic trees by the neighbour-joining method.

\section{Antibiogram of isolated Salmonella strains}

Antimicrobial susceptibility testing was performed using the disc diffusion method. The result was interpreted as per the recommendation of the National Committee for Clinical Laboratory Standards Institute (CLSI) (CLSI, 2016; Abdi et al., 2017). The isolated Salmonella strains were subcultured on nutrient agar medium, and then single colonies were transferred into tubes containing $5 \mathrm{~mL}$ of sterile saline. The bacterial density was matched with 0.5 McFarland turbidity standard, which was equal to $1.5 \times 10^{8}$ bacterial cells $/ \mathrm{mL}$. A sterile cotton swab was used to spread the inoculum uniformly over the surface of the Muller Hinton agar plate by the spreading method. The plates were held at room temperature for $30 \mathrm{~min}$ to allow for drying and then tested for gentamicin $(\mathrm{CN}) 10 \mu \mathrm{g}$, CIP $5 \mu \mathrm{g}$, chloramphenicol (C) $30 \mu \mathrm{g}$, CTX 30 $\mu \mathrm{g}$, cefoperazone/sulbactam (CES) 75/30 $\mu \mathrm{g}$, AZM $(30 \mu \mathrm{g})$, meropenem (MEM) 10 $\mu \mathrm{g}$, imipenem (IPM) $10 \mu \mathrm{g}$ and levofloxacin (LEV) $5 \mu \mathrm{g}$. The plates were incubated at $37^{\circ} \mathrm{C}$ for $24 \mathrm{hrs}$. The diameter of the zones of inhibition was classified as resistant, intermediate, or susceptible according to the CLSI (2016). All antibiotic discs were manufactured at Oxoid Ltd., England, and the expiry dates were 2018 .

\section{Results}

\section{Isolation and characterization of local Egyptian Salmonella strains}

Twenty-eight local Egyptian Salmonella isolates were recovered. Seven isolates were from human stool, 10 were from carriers (Egyptian cattle egret and stork) and 11 isolates were from grilled chickens from multilayer electric grills. No isolates were recovered from grilled chick-
Table 1. The set of $i n v A$ gene primers for diagnosis of Salmonella isolates.

$\begin{array}{llll}\text { Gene } & \text { Sequence } & \text { Product } & \text { Ref. } \\ \text { invA F } & \text { 5- GTG AAA TTA TCG CCA CGT TCG GGC AA -3 } & 281 \mathrm{bp} & \text { Rahn et al., } 1992 \\ \text { invA R } & \text { 5- TCA TCG CAC CGT CAA AGG AAC C -3 } & & \end{array}$


ens on charcoal grills or from drinking water. The Salmonella isolates gave the typical colonial morphology on the selective media, which was colourless colonies with a black centre on XLD agar medium and transparent and black colonies on HE agar medium. The biochemical identification revealed that all local Salmonella strains were TSI K/A-positive with $\mathrm{H}_{2} \mathrm{~S}$ production, negative for the urea hydrolysis test, and citrate-positive.

\section{Serological identification of Salmonella isolates}

The serotyping analysis of Egyptian Salmonella strains showed that all Salmonella isolates from carriers (10 isolates) and grilled chickens from multilayer electric grills (11 isolates) were $S$. typhimurium $(100 \%)$. The human strains varied between $S$. typhimurium (42.8\%), $S$. enteritidis (14.3\%), S. virchow (14.3\%), $S$. haifa (14.3\%) and S. kentucky (14.3\%). Of the 28 total Salmonella isolates in the present study, $S$. typhimurium represented $86 \%$, and the other serotypes each represented $3.5 \%$ of the total isolates (Table 2).

\section{Molecular diagnosis by invA gene PCR}

All 28 local Egyptian isolates were PCR-positive for the invA gene, which was detected by electrophoresis of the target band at $281 \mathrm{bp}$ of the invA gene product (Figure 1).

Invasive protein A (invA) gene product sequencing and bioinformatics analysis

Representative sequences from this study were deposited into the GenBank database under accession numbers MF953387, MF953388 and MF953389. The invA gene nucleotide sequence data available at GenBank were selected based on the criteria of the information available regarding the isolation source, location and year (Table 3). Three amplified PCR products of the invA gene were sequenced and aligned with the other related invA gene sequences obtained from GenBank NCBIBLAST. The $\leq 99 \%$ sequence identity to the invA gene of $S$. enterica strains showed that the set of primers described in the present study exclusively amplifies the $281 \mathrm{bp}$ fragment of the target gene. Phylogenetic anal-

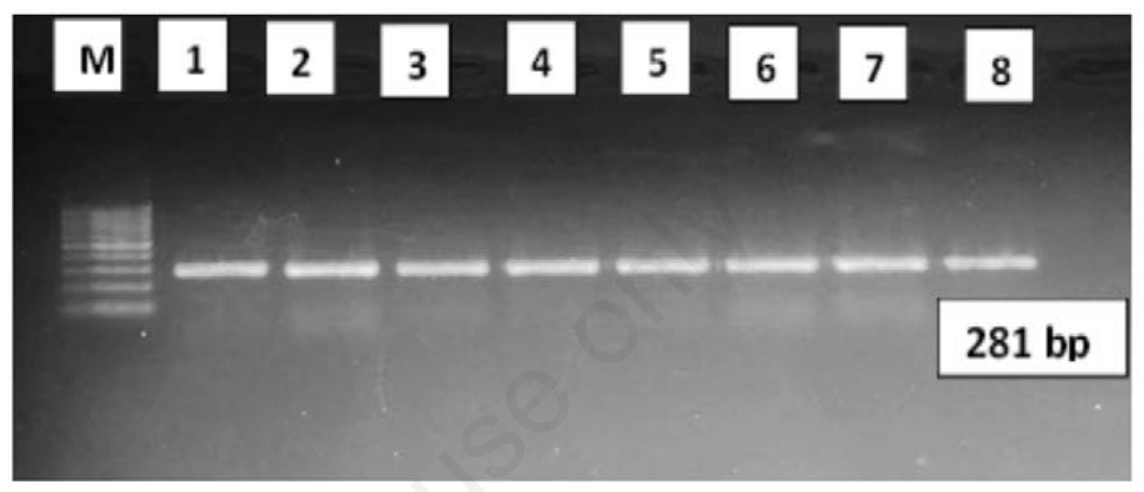

Figure 1. Molecular detection of Salmonella isolates by invA gene PCR for detection of 281 bp gene product in Salmonella isolate genome. (M) 100 bp DNA ladder. (1 to 8) Salmonella isolate genome.

Table 2. Serotyping analysis of the 28 Salmonella Egyptian isolates from human stool, stork carriers and grilled chickens from multilayer electric grills.

\begin{tabular}{|c|c|c|c|c|}
\hline Salmonella serotype & Humans (7), (\%) & $\begin{array}{l}\text { Type } \\
\text { Storks (10) }\end{array}$ & Grilled chickens (11) & Total no. (\%) \\
\hline S. Typhimurium & $3(42.8)$ & All 10 isolates (100\%) & All 11 isolates (100\%) & $24(86)$ \\
\hline S. enteritidis & $1(14.3)$ & - & - & $1(3.5)$ \\
\hline S. virchow & $1(14.3)$ & - & - & $1(3.5)$ \\
\hline S. haifa & $1(14.3)$ & - & - & $1(3.5)$ \\
\hline S. kentucky & $1(14.3)$ & - & - & $1(3.5)$ \\
\hline
\end{tabular}

Table 3. GenBank accession no. and epidemiological information of nucleotide sequences used in phylogenetic analysis encoding the invA protein.

\begin{tabular}{llllll} 
Sample no. & Serotype & Isolation source & Location & Sample collection date & Accession no. \\
1 & Salmonella Heidelberg & Broilers & Egypt & - & ARS88237 \\
2 & Salmonella enterica & Broilers & Egypt & - & AID54915 \\
\hline 3 & Salmonella cerro & Cattle faecal sample & USA & ETC76711 \\
4 & Salmonella enterica & Chicken & China & - & AHA92023 \\
\hline 5 & Salmonella Enteritidis & Ground turkey & USA & - & ELL58393 \\
6 & Salmonella Typhimurium & Food sample & Portugal & 2011 & KNB31714 \\
\hline 7 & Salmonella Cubana & Desiccated coconut & Philippines & 1972 & ESJ52477 \\
8 & Salmonella enterica & Human stool & India & 2015 & KYN92226 \\
\hline $9 *$ & Salmonella Typhimurium & Stork wild bird) & Egypt & 2016 & MF953387 \\
$10^{*}$ & Salmonella Typhimurium & Grilled chicken & Egypt & 2016 & MF953388 \\
\hline $11 *$ & Salmonella Typhimurium & Human stool & Egypt & 2017 & MF953389 \\
\hline
\end{tabular}

*Gene sequences enrolled in the present study. 
ysis results of $3 \mathrm{~S}$. enterica isolates based on invA gene sequences are shown in Figure 2. The invA gene sequences of these isolates were initially compared to those of $S$. enterica strains reported in the GenBank database (Table 3).

Occurrence of Salmonella isolates in Egypt

One hundred seventy-five samples were collected from different sources from different areas in Egypt in 2016-2017. The occurrence rate of Salmonella isolates found in Table 4 shows a $12.6 \%$ occurrence rate in rural areas and a $19.3 \%$ occurrence rate in urban areas with no significance, with a $\mathrm{P}$ value of $0.235(\mathrm{P}<0.05)$. The occurrence rate according to sample type showed that $9.3 \%$ of samples were from human stool, $28.5 \%$ were from carriers, $36.6 \%$ were from grilled chickens from multilayer electric grills, and $0 \%$ were from grilled chickens from charcoal grills and drinking water, with a highly significant $P$ value of 0.0002 $(\mathrm{P}<0.05)$.

\section{Antibiogram of Salmonella isolates}

All Salmonella isolates were intermediate resistant (I) for CIP-I (100\%), twenty isolates were intermediate resistant (I) for AZM-I (71.4\%), sixteen isolates were CN resistant (57\%), and four isolates were multidrug resistant (MDR) (resistant for $\geq 3$ antimicrobial drugs) for CTX, AZM and $\mathrm{CN}$, which were isolated from grilled chickens. All isolates were susceptible to C, LEV, CES, IPM and MEM (Table 5).
Phenotypic pattern of antimicrobial resistance

Approximately $14.6 \%$ of Salmonella isolates were MDR, and their pattern was CTX*AZM*CN*CIP-I. They were isolated from chickens in multilayer electric grills ( $S$. typhimurium). These isolates were resistant to all types of antimicrobial drugs used in routine treatment of salmonellosis at different ages. Nine isolates (32\%) (3 isolates from grilled chickens and 6 from humans) had the CN*CIP-I*AZM-I pattern. Approximately $39.2 \%$ of Salmonella isolates had the CIP-I*AZM-I pattern ( 3 isolates from grilled chickens, 7 from carriers and one from humans). Three carriers of $S$.

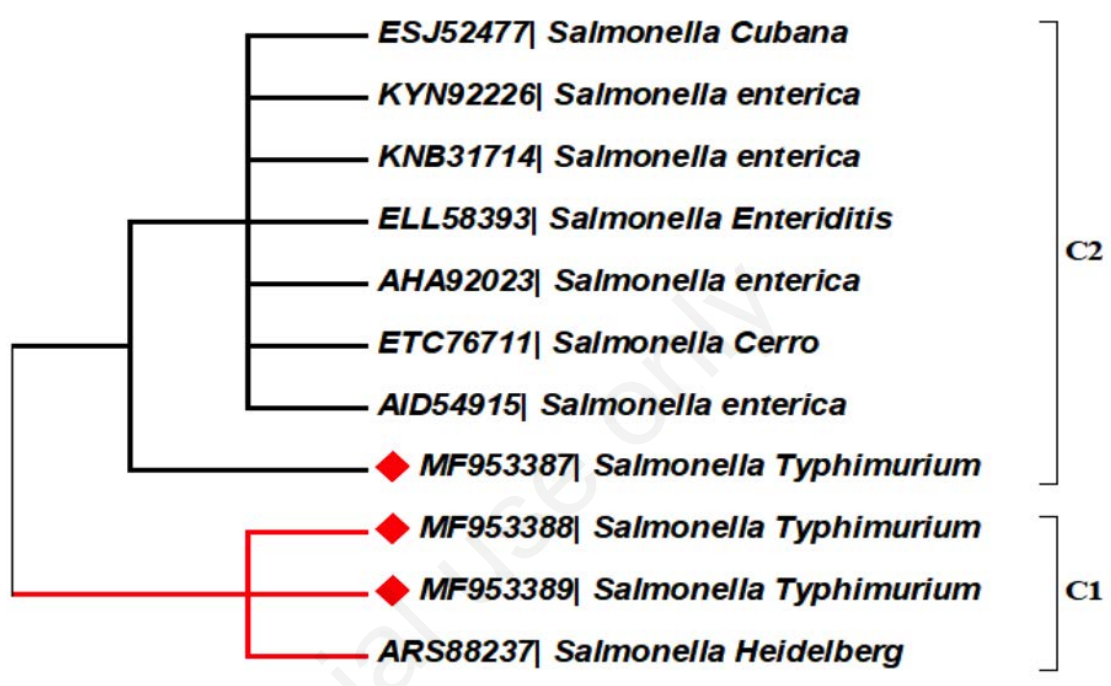

Figure 2. Neighbour-joining phylogenetic tree based on invA gene sequences showing the relationship between the present study sequences and 8 representative sequences retrieved from GenBank. The accession numbers of sequences are shown on the branches. The isolate sequenced in this study is indicated by red diamond.

Table 4. Occurrence rate of Salmonella isolates from different sources in different areas in Egypt.

\begin{tabular}{llcccc} 
Risk factor & & No. of samples & No. of positive & Prevalence rate $(\%)$ & P value $(<0.05)$ \\
\multirow{2}{*}{ Area of study } & Rural (Qwesna) & 87 & 11 & 12.6 & 0.235 (No significance) \\
& Urban (Giza, Cairo) & 88 & 17 & 19.3 & 0.0002 (High significance) \\
\multirow{2}{*}{ Type of sample } & Human & 75 & 7 & 28.5 & 36.6 \\
& Carrier stork & 35 & 11 & 0 & 0 \\
& Electric grilled chicken & 30 & 0 & 0 & 0 \\
& Charcoal grilled chicken & 20 & 15 & & \\
& Drinking water & &
\end{tabular}

Table 5. Antibiogram analysis of Salmonella isolates from grilled chickens, human stool and carriers towards nine antibiotic discs.

\begin{tabular}{|c|c|c|c|c|c|c|c|c|c|}
\hline \multirow{2}{*}{ Salmonella isolates } & \multicolumn{8}{|c|}{ Antibiotic dises } & \multirow[b]{2}{*}{ LEV } \\
\hline & CTX & CIP & AZM & $\mathrm{CN}$ & CES & C & MEM & IPM & \\
\hline \multirow[t]{4}{*}{ Chicken Salmonella isolates } & S & IR & IR & S & S & S & $\mathrm{S}$ & S & $\mathrm{S}$ \\
\hline & S & $\mathrm{IR}$ & IR & $\mathrm{R}$ & S & S & S & S & S \\
\hline & S & IR & $\mathrm{S}$ & IR & S & S & S & S & S \\
\hline & $\mathrm{R}$ & IR & $\mathrm{R}$ & $\mathrm{R}$ & S & S & $\mathrm{S}$ & S & S \\
\hline \multirow[t]{2}{*}{ Human Salmonella isolates } & S & IR & IR & S & S & S & S & S & S \\
\hline & S & IR & IR & $\mathrm{R}$ & S & S & S & S & S \\
\hline \multirow[t]{3}{*}{ Salmonella isolates from carriers } & S & IR & $\mathrm{S}$ & $\mathrm{R}$ & S & S & S & S & S \\
\hline & S & $\mathrm{IR}$ & IR & $\mathrm{S}$ & S & $\mathrm{S}$ & $\mathrm{S}$ & $\mathrm{S}$ & $\mathrm{S}$ \\
\hline & S & IR & IR & $\mathrm{S}$ & S & S & S & S & S \\
\hline
\end{tabular}


typhimurium isolates had the $\mathrm{CN}^{*} \mathrm{CIP}-\mathrm{I}$ pattern $(10.7 \%)$, and one $S$. typhimurium strain from grilled chickens had the $\mathrm{CN}$ I*CIP-I pattern $(3.5 \%)$ (Table 6).

\section{Discussion}

Salmonella infection is widespread, especially in developed countries (Ramadan et al., 1992; Schutze et al., 1997). Salmonellosis is underdiagnosed because samples are not obtained for culturing; only the serum is taken for the Widal test, which depends only on circulating blood antibodies against typhoidal Salmonella O/H antigens. The Widal test has many limitations, including that the result of a single test has no diagnostic significance in an endemic region according to WHO recommendations. This is due to the difficulty in establishing the baseline titre of Widal agglutination, which limits the usefulness of the test as a reliable diagnostic indicator of the disease process (Baired-Parker, 1990; Keusch, 1998). During 2016-2017, recurrent salmonellosis increased due to poor socioeconomic factors, poor hygiene, and misuse of antibiotics, which led to the spread of antimicrobial-resistant (AMR) Salmonella strains.

In the present study, 28 obtained Salmonella isolates were identified culturally and biochemically. Serological characterization revealed that the main serotype was $S$. typhimurium, which was found in approximately $86 \%$ of the total isolates; $100 \%$ of the isolates were recovered from carriers and grilled chickens from multilayer electric grills (the main risk factor for typhoidal salmonellosis). Human isolates varied between $S$. typhimurium (42.8\%), with the highest prevalence, $S$. enteritidis $(14.3 \%), S$. virchow $(14.3 \%), S$. haifa $(14.3 \%)$ and $S$. kentucky (14.3\%). Molecular characterization by invA gene PCR was considered the most common diagnostic marker until now (O'Regan et al., 2008; ElSharkawy et al., 2017). The invasive protein A (invA) gene is a critical virulence determinant of Salmonella because of its role in invasion of the host epithelial cell layer.

Table 6. AMR patterns of all Salmonella isolates.

\begin{tabular}{|c|c|c|c|}
\hline AMR pattern & Number of AMR isolates & Number of isolates & Prevalence rate \% \\
\hline CIP-I*AZM-I & 0 (CIP-I, AZM-I) & 11 & 39.2 \\
\hline CN*CIP-I*AZM-I & 1(CIP-I, AZM-I) & 9 & 32 \\
\hline CN-I*CIP-I & $0(\mathrm{CN}-\mathrm{I}, \mathrm{CIP}-\mathrm{I})$ & 1 & 3.5 \\
\hline CTX*AZM*CN*CIP-I & $3(\mathrm{CIP}-\mathrm{I})$ & 4 & 14.6 \\
\hline CN*CIP-I & $1(\mathrm{CIP}-\mathrm{I})$ & 3 & 10.7 \\
\hline
\end{tabular}

DNA sequencing and bioinformatics analyses were performed to confirm the PCR results in our study and compared with the GenBank NCBI-BLAST database. Regarding the present study sequences, we found $\leq 99 \%$ sequence similarity to inv $\mathrm{A}$ gene sequences of $S$. enterica strains with different serotypes available in the GenBank database, which has been confirmed by others to be the invA gene, which contains sequences unique to Salmonella; this gene is a suitable PCR target. Phylogenetic analysis of $S$. enterica serotypes (Figure 2) using the sequences of the invasion protein $\mathrm{A}$ (invA) gene showed that the sequences recovered from 3 isolates in this study had accession numbers of MF953387, MF953388 and MF953389, and 8 isolates retrieved from GenBank (Table 3) were grouped into two clusters (C1\&C2). C1 showed that our study sequence isolated from carriers (wild bird) (MF953387) was in a close relationship with other sequences retrieved from GenBank (Figure 2), which include different hosts, isolation source, locality and isolation dates. This finding highlights the public health hazard of the spread of some wild birds, such as the Egyptian cattle egret and stork. The second cluster (C2) showed that our study sequences isolated from grilled chickens (MF953388) and humans (MF953389) are closely related to the sequence (ARS88237) retrieved from GenBank isolated from broilers. This relationship poses the greatest risk to public health and the human incidence of salmonellosis transmitted indirectly through foodstuffs (Wegener et al., 2003). From the phylogenetic tree analysis, it is clear that there is a high degree of convergence between grilled chicken and human sequences, which confirms what was previously discussed, as negligence and mishandling during the preparation of grilled chicken may act as potential sources for cross contamination. Consistent with the aforementioned data, poor personal hygiene practices of food handlers, improper food processing, and inadequacy of both education of food handlers and information directed to consumers all make foodborne diseases still dominant as the most imporrelated invA gene sequences retrieved from tant public health problems in most countries (Ulaya, 2013).

There was no significance regarding area of study in the Salmonella infection occurrence, but sample type showed high significance regarding the Salmonella infection occurrence, which is considered an important risk factor (Table 4).

From the aforementioned data, the Salmonella occurrence scenarios could be explained as follows. First, in rural areas, the expected route of Salmonella infection is eating of food contaminated vegetables and fruits. The agricultural lands are irrigated with sewage, and the Egyptian cattle egret and stork stand in both sewage and agricultural lands, which facilitates Salmonella contamination and the spread of the infection to different locations. Then, the contaminated vegetables and fruits are eaten fresh, without washing, by farmers, sellers and clients in vegetable and fruit markets. Second, in urban areas, the expected route of infection is eating of contaminated fast food, such as grilled chicken in electric multilayer grills $(36.6 \%$ prevalence rate) in contrast to grilled chickens on charcoal grills $(0 \%$ occurance). The cooks in most restaurants handle cooked and uncooked food at the same time, which helps spread the infection to consumers. Most restaurants use electric multilayer grills, which cook high amounts of chicken and other meat. In these types of grills, the upper layer is cooked faster than the lower one, and then the cooks exchange the raw chicken with cooked ones, which allows for contamination of the cooked chickens by the water droplets that fall from the uncooked ones. The cooks take the contaminated cooked grilled chicken to the clients, who acquire the infection and are now at risk. Furthermore, tracing the AMR patterns of Salmonella isolates is extremely important. In the study locations, after checking the most common physician advice for patients, we found that salmonellosis is treated mainly by the following regimens: patients $>18$ years are treated with CIP, and patients $<18$ years are treated with CTX for 3 days, and the regimen is completed with AZM. The high recurrence rate of infection, improper habits of consumers, poor hygiene practices and misuse of antibiotics are all reasons we need to evaluate the treatment protocols for salmonellosis and test the antimicrobial susceptibility to other available antimicrobial drugs. As mentioned in Table 5, CIP, which is most advisable for salmonellosis treatment, is not sufficiently effective on Salmonella isolates. CTX, the most effective drug for salmonellosis in young patients, began to lose its effectiveness because a new generation of MDR 
Salmonella strains that are resistant to CTX, AZM and $\mathrm{CN}$ appeared (Table 6). AZM also lost its effectiveness on most Salmonella isolates in the current study. Thus, the consequences of the misuse of antibiotics are the development of AMR Salmonella strains and the ineffectiveness of routine treatment regimens for salmonellosis. Antimicrobial susceptibility testing of Salmonella isolates (shown in Table 5) showed that all Salmonella isolates could be treated with LEV, CES, C, IPM and MEM.

\section{Conclusions}

Salmonella bacteria are highly dangerous foodborne pathogens that cause considerable hazards to public health in our country. The socioeconomic factors of poor habits of consumers, poor hygiene practices, misuse of antibiotics and improper lifestyle are the main factors in the generation of new MDR strains of Salmonella. Therefore, informing the public by authorized communities is very important.

\section{References}

Abdi RD, Mengstie F, Beyi AF, Beyene T, Waktole H, Mammo B, Ayana D, Abunna F, 2017. Determination of the sources and antimicrobial resistance patterns of Salmonella isolated from the poultry industry in Southern Ethiopia. BMC Infect Dis 17:352-63.

Allerberger F, Liesegang A, Grif K, Khaschabi D, Prager R, Danzl J, Höck F., Öttl J., Dierich MP, Berghold C, Neckstaller I, Tschäpe H, Fisher I, 2003. Occurrence of Salmonella entericaserovar Dublin in Austria. Wien Med Wochenschr 153:148-52.

Baired-Parker AC, 1990. Foodborne Salmonellosis. Lancet 336:1231-5.

Barlow M, Hall BG, 2002. Origin and evo- lution of the AmpC beta-lactamases of Citrobacterfreundii. Antimicrob Agents Chemother 46:1190-8.

Chiu CH, Wu TL, Su LH, Chu C, Chia JH, Kuo AJ, Chien MS, Lin TY, 2002. The emergence in Taiwan of fluoroquinolone resistance in Salmonella enterica serotype choleraesuis. New Engl J Med 346:413-9.

CLSI, M100-S26, 2016. Performance standards for antimicrobial susceptiblity testing: $26^{\text {th }}$ informational supplement. Wayne, PA: Clinical and Laboratory Standards Institute.

Crump JA, Luby SP, Mintz ED, 2004. The global burden of typhoid fever. Bull WHO 82:346-53.

ElSharkawy H, Tahoun A, ElGohary AA, ElAbasy M, ElKhayat F, Gillespie T, Kitade Y, Hafez HM, Neubauer H, El-Adawy H, 2017. Epidemiological, molecular characterization and antibiotic resistance of Salmonella entericaserovars isolated from chicken farms in Egypt. Gut Pathogens 9:8-19.

ISO 6579,1993 . (E) $3^{\text {rd }}$ ed. MicrobiologyGeneral guidance on methods for the detection of Salmonella.

Kauffmann F, 1961. Die Bakteriologie der Salmonella-Species. Kopenhagen, Munksgaard.

Keusch GT, 1998. Salmonellosis. In Harrison's principals of internal Medicine $14^{\text {the }}$ edn. New York: McGrawHill. pp 950-956.

Majowicz SE, Musto J, Scallan E, Angulo FJ, Kirk M, O'Brien SJ, Jones JF, Fazil A, Hoekstra RM, 2010. The global burden of non-typhoidal Salmonella gastroenteritis. Clin Infect Dis 50:882-9.

O'Regan E, McCabe E, Burgess C, McGuinness S, Barry T, Duffy G, Whyte P, Fanning S, 2008. Development of a real-time multiplex PCR assay for the detection of multiple Salmonella serotypes in chicken samples. BMC Microbiol 8:1.

Post DE, 1997. Food-borne pathogens monograph number I Salmonella. Oxoid limited, Hampshire.

Pui CF, Wong WC, Chai LC, Nillian E, Ghazali FM, Cheah YK, Nakaguchi Y, Nishibuchi M, Radu S, 2011. Simultaneous detection of Salmonella spp., Salmonella Typhi and Salmonella Typhimurium in sliced fruits using multiplex PCR. Food Control 22:337-42.

Rahn K, de Grandis SA, Clarke RC, McEwen SA, Galán JE, Ginocchio C, Curtiss R, Gyles CL, 1992. Amplification of an invA gene sequence of Salmonella typhimurium by polymerase chain reaction as a specific method of detection of Salmonella. Mol Cell Probes 6:271-9.

Ramadan F, Unni AG, Hablas R, Rizk MS, 1992. Salmonella-induced enteritis, clinical, serotypes and treatment. J Egypt Public Health Assoc 67:357-67.

Schutze GE, Schutze SE, Kirby RS, 1997. Extraintestinal Salmonellosis in children's hospitals. Pediatr Infect Dis J $16: 482-5$

Silva J, Leite D, Fernandes M, Mena C, Gibbs PA, Teixeira P, 2011. Campylobacter spp. as a foodborne pathogen: a review. Front Microbiol 2:200.

Ulaya WD, 2013. Determination of virulence factors in salmonella isolates of human, poultry and dog origin in Lusaka district, Zambia. M.V.Sc Thesis, The university of Zambia school of veterinary medicine Dept. of Paraclinical Studies lusaka.

Wang RF, Cao WW, Cerniglia CE, 1996. PCR detection and quantitation of predominant anaerobic bacteria in human and animal fecal samples. Appl Environ Microbiol 62:1242-7.

Wegener HC, Hald T, Wong DLF, Madsen M, Korsgaard H, Bager F, 2003. Salmonella control programs in Denmark. Emerg Infect Dis 7:774-80. 